\title{
Velmezova, E.: Les lois du sens: la sémantique marriste (Slavica Helvetica, 77), Bern, etc. Peter Lang, 2007, 392 pp.
}

\author{
Andries van Helden
}

Published online: 11 September 2009

(C) The Author(s) 2009. This article is published with open access at Springerlink.com

\begin{abstract}
The discussion of Velmezova's epistemological analysis of Marrism focuses on four questions: what did Marr say, where did his views come from, why did they gain acceptance, and do Velmezova's findings affect Marr's place in the history of linguistics?

Velmezova treats Marrism as the application to language of the historical approach to the human sciences that dominated 1920s Soviet Marxist thought. Viewed in this light, Marr's theories are more coherent and less idiosyncratic than in their usual presentation. His central underlying tenet was the law of diffuse semantics: in the course of the evolution of mankind, amorphous unarticulated meanings have developed into well-defined units that can be combined into complex articulated messages. The law is a particular instance of a general evolutionary principle formulated by Herbert Spencer.

Applying both Sylvain Auroux's principle of epistemological neutrality and Patrick Sériot's conception of air du temps, Velmezova includes non-scientific elements in her source material while limiting its epistemological environment to intellectual discourse, risking to neglect any non-intellectual sources of Marrism and factors explaining its acceptance, such as Caucasian politics, university politics and Marr's private life. This prevents Velmezova's results from prompting a radical revision of Marr's present image.
\end{abstract}

Аннотация Эпистемологический анализ Нового учения о языке Н. Я. Марра в книге Е. В. Вельмезовой может обсуждаться по вопросам: В чем суть марровского учения? Каковы его истоки? Почему оно получило признание? Какое отношение имеют результаты исследования к положению Марра в истории языкознания?

Unlike Van Helden (2008), the present discussion is an evaluation of the book, exploring in some depth and detail a few issues that can only be touched upon in a three-page review.-When the present paper was composed, C. Brandist's short review of Velmezova's book in Historiographica Linguistica (35(1/2), 2008, pp. 208-212) was not yet available to the author. Meanwhile, Velmezova has published a reply and Brandist has published a rejoinder in Historiographica Linguistica (36(1), 2009, pp. 193-197 and 199-201), respectively.

W. A. van Helden $(\bowtie)$

Leiden University Centre for Linguistics (Slavic), Universiteit Leiden,

P. N. van Eyckhof 2 (1164/203c), 2311 BV, Leiden, The Netherlands

e-mail: w.a.van.helden@hum.leodenuniv.nl 
В работе Вельмезовой учение Марра трактуется не просто как отрасль языкознания, а скорее как применение к языку популярного среди марксистских интеллигентов 20-х гг. прошлого века единого исторического подхода к гуманитарным наукам. В этом отношении, взгляды Марра оказываются более состоятельными-и менее эксцентричными-чем в их обыкновенной трактовке. Главным принципом марризма, по-видимому, является закон диффузной семантики: в ходе прогресса человечества, по мнению Марра, неоформленные семантические единицы первобытного языка постепенно развиваются в четкие единицы мышления, поддающиеся сочетанию в комплексных сочлененных сообщениях. Закон можно рассматривать как особый случай общей эволюционной закономерности, сформулированной Гербертом Спенсером.

Придерживаясь принципа эпистемологического нейтралитета, сформулированного Сильвеном Ору, и пользуясь понятием air du temps в понимании Патрика Серио, автор, с одной стороны, отказывается от разделения научных и ненаучных элементов, заключающихся в марровском учении, а, с другой стороны, ищет его истоки и причины его признания только в интеллектуальной среде, не считаясь с тем, что содержанию или распространению Нового учения могли способствовать и такие неинтеллектуальные факторы, как политические отношения на Кавказе, перестройки в Ленинградском университете и советских научных учреждениях, личная жизнь самого Марра, и т.д. Поэтому итоги книги не являются поводом для коренной переоценки научного значения Марра.

Keywords Marrism - Soviet sociolinguistics · air du temps · epistemological neutrality · semantic laws $\cdot$ glottogenesis

\section{Introduction}

\subsection{Marr reception outside the Soviet Union}

Whereas such widely read journals as Science and Nature kept Western intellectuals up to date about T. D. Lysenko's theories and affairs since the mid 1930s, N. Ja. Marr (1864/1865-1934) and his New Teaching on Language (also known as the Japhetic Theory) largely passed unnoticed abroad. Marr's frequent and long visits to Western Europe in the 1920s had yielded little more than a French version of his Georgian grammar (Marr and Brière 1931) edited by Marr's Parisian student, the canon Maurice Brière (18811960). Besides some isolated comments from émigré linguists (e.g. Trubetzkoy 1924), the reception of Marr's work was limited to a few (negative) analyses on the part of Marxist linguists (Sköld 1929, 80-87; Sauvageot 1935) and specialists in Caucasian languages (e.g. Vogt 1933). ${ }^{1}$

Marr gained some posthumous renown in the West after Stalin's denunciation of his views in Pravda in 1950 but, with the notable exception of Ellis and Davies (1951), most scholarly interest focused on Stalin's arguments and the possible political implications of Stalin's démarche rather than on Marr's views.

In the late 1960s, however, Marr came into vogue in Continental leftist circles, as he could be presented as a sufficiently Marxist alternative to Stalinism: 'in their pursuit of

\footnotetext{
${ }^{1}$ Vogt (1933, 144-145) criticized Marr and Brière's grammar for being infected by the New Teaching to the extent of mixing, in its morphological paradigms, Old and Modern Georgian as well as Gurian dialect forms not attested elsewhere and even entirely fictitious forms.
} 
a 'social' linguistics, [the Marrists] have supplied contributions that, accompanied by the necessary criticism, are still useful today' (Borbé 1974, 3, quoting Étienne Balibar). Marr's ideas were approached with a neutral or even positive attitude, (e.g. Marcellesi 1977) and translations of some of his work were published, including the so-called Baku lectures (i.e. Marr 1974).

In the 1980s, Bjørnflaten's (1982) and L'Hermitte's (1987) monographs contributed to establishing Marr's reputation as a linguistic Lysenko: his uncompromising ambition was believed to have driven him to use ruthless methods, both before the Revolution and after, to oust his Academic opponents and impose his quasi-scientific concoctions on his fellow-linguists.

With Perestrojka, the archives opened up and eyewitnesses (or their widows and offspring) started handing over their reminiscences to the historians. A great deal of the new information on Marr's life and times that became available found its way into Alpatov (1991), which is the most complete work on the Marr phenomenon to date. Alpatov puts Marr and his followers into their historical context and in some respects mitigates the Lysenko analogy; nevertheless, he concludes that Marr's views are not to be rehabilitated (Alpatov 1991, 220).

Rather than being the definitive word on Marr, Alpatov's book triggered a substantial flow of publications, not only on historical details but also on Marr and Marrism as facets of broader trends in 1920s Soviet science and society. At present the study of 'Soviet sociolinguistics', referring to linguistic theories and methods inspired by Marxist social thought in the 1920s and 1930s and including Marrism as its most colourful variety, has become a popular research topic among historians and sociologists of science as well as linguists and general historians. The proceedings of a conference on the 'lost paradigm' of Marrism, held near Lausanne in 2004, contains contributions by twenty-two authors from various countries in Western and Eastern Europe (Sériot 2005). It has currently become a considerable task to catch up and keep up with the literature on Marr, let alone provide original contributions to it. $^{2}$

\subsection{Marr exegesis}

Authentic, coherent and accessible accounts of Marr's actual linguistic views are, however, rare. Marxists confined themselves to checking Marr's consistency with Marxism; other analysts tend to avoid the substance of his theories, concentrating on the contextual aspects of the Marr phenomenon. As a consequence, the New Teaching is often presented as a collection of isolated tenets, to be examined and rejected (usually on empirical grounds) one by one, rather than as an integral intellectual construct, to be examined and evaluated as a whole.

Marr himself is the first to blame for this. He devoted thousands of pages to his theory but even native speakers of the languages in which his texts were published (usually Russian, sometimes Georgian or Armenian) lose their bearings when faced with his abstruse discourse and formalism. Marr's insights, moreover, have been in a permanent state of flux: he disavowed the Baku Lectures, which contained just about the only integral presentation of them he ever produced himself (Meshchaninov 1951, 24). Judging by contemporary students' assessments, Marr's style of teaching was chaotic (cf. D'jakonov 1995, 316) or, if one wishes, charismatic (cf. Frejdenberg (1988) 2001, 426), and his staff

\footnotetext{
${ }^{2}$ Space does not permit enumerating even the major publications of the past two decades but most of them are referred to in the book under discussion, Slezkine (1996) being a notable omission.
} 
disagreed on the correct interpretation of his views even during his lifetime. ${ }^{3}$ Several independent analysts too, failing to find any apparent coherence in Marr's work, dismissed him as a charlatan or a lunatic ${ }^{4}$ or at best blamed themselves for failing to share his genial intuitions. $^{5}$

\section{Thomas' contribution}

Thomas' (1957) meticulous analysis of Marr's theories, which came out when the interest in Marr was at a low, is the most prominent exception to the observations made above. Besides providing biographical information, Thomas makes a considerable effort to explicate Marr's linguistic views and methods. He concludes that, "despite the contradictions and alterations, Marr's theories [in fact] show a remarkably coherent and orderly development" (Thomas 1957, 135). As Thomas demonstrates, this development had started long before the Revolution. Its coherence, he makes clear, is not, however, of an intellectual but of a voluntarist character: Marr was guided by the desire to produce what nowadays would be referred to as a politically correct theory, or more specifically: any theory that supports the claim that the peoples of the Caucasus or, by extension, oppressed minorities in general, from Basks to Hottentots, ${ }^{6}$ are not isolated, marginal and residual populations but have played an essential role in the linguistic and cultural development of mankind. "Marr's entire career was an attempt to restore to them their place in the sun" (Thomas 1957, 144).

\subsection{Velmezova's contribution}

Within the vast body of scholarly literature on Marr, the book under discussion is probably best compared with Thomas (1957). Even more than Thomas, Ekaterina Velmezova (E. V. Vel'mezova) abstracts from the biographical, institutional and political contexts of Marr's theories and focuses on the New Teaching as an autonomous intellectual universe, to be analysed as it presents itself and to be explained in terms of its differences from and resemblances to other intellectual constructs. She explores relationships between Marr's views and those of other scholars in greater depth than Thomas did.

\section{Synchronic analysis}

Velmezova has not adopted Thomas' method of dissecting Marr's thinking diachronically, i.e. as developing over time. She takes a basically synchronic approach, assuming that, in spite of all the flux on the surface, the New Teaching is founded on an essentially coherent

\footnotetext{
${ }^{3}$ Aptekar' $(1929,264)$, for example, accused Meščaninov of distorting Marr's theory in his survey of the New Teaching (Meščaninov 1929) by presenting Version 5 as its canonical version instead of Version 7. The latter (Meščaninov 1934) returned the accusation in his destructive review of Aptekar's (1933) synthesis of the New Teaching, although it consisted exclusively of quotations from Marr's writings. The most insightful contemporary presentation of Marr's views was perhaps the one given by the Marxist historian Kovalev (1928).

${ }^{4}$ Sköld $(1929,82)$ characterized Marr as an illusionist and self-deceiver. Trubetzkoy $(1924,74)$ deemed that only psychiatrists were qualified to review Marr's work.

${ }^{5}$ Gamkrelidze (1989, 3-4), although not subscribing to the logic of Marr's theory, extolled Marr's intuitions, leading him to subconsciously copying the structure of the genetic code into his theory of language as an information-carrying system.

${ }^{6}$ The titles of Marr ((1928) 1937) ('From Pyrenean Guria') and Marr ((1927) 1937) ('Hottentots are Mediterraneans') speak for themselves.
} 
intellectual core of underlying assumptions and concepts: until proof to the contrary is found, any inconsistencies and fluctuations must be considered to pertain to marginal aspects. In practice her analysis is based on the later versions of the New Teaching.

\section{Epistemological analysis}

As a historian of linguistics, Velmezova has set herself the task of providing an epistemological analysis of the New Teaching (45), ${ }^{7}$ in which its coherent core is identified and presented as explicitly as possible. She regards the semantic analysis of the terminology used in the primary sources as an important tool for finding and understanding the relevant concepts and assumptions (58).

\section{Epistemological neutrality}

Velmezova subscribes, moreover, to the principle of epistemological neutrality. Citing Sylvain Auroux's position that it is not up to the historian of science to decide on the limits of science (55), ${ }^{8}$ she refrains from measuring Marr's assumptions, concepts and methods by normative standards that derive from alien paradigms. Unlike Thomas and most other analysts, Velmezova does not engage in a discussion of the consistency and empirical adequacy of Marr's theories: her main goal is to expound and compare the views presented, not to discuss whether and why they might be regarded as incorrect.

\section{The format of Velmezova's book}

In order to fulfil her complex assignment, Velmezova has systematically worked her way through the five bulky volumes of Marr's Selected Works that appeared in the 1930s ${ }^{9}$ (which has even enabled her to adduce statistics on issues where Marr contradicts himself: e.g. 109, 181). She has also explored about a thousand scholarly documents found in Marr's archive, including unpublished articles, and has consulted work written by Marr's collaborators and students, especially I. I. Meščaninov (1883-1967) and V. I. Abaev (19002001).

The resulting monograph consists of three parts besides a lengthy introduction. Part I describes the state of linguistics when Marr developed the New Teaching; Part II, which is the pièce de résistance of the book, discusses six of Marr's semantic laws and explores their intellectual origins; Part III deals with the reception of Marrism.

\subsection{The present discussion}

The structure of Velmezova's book is, however, ignored in the present discussion, which, at the risk of neglecting certain important aspects that Velmezova brings up, concentrates on her contribution to the following issues and is structured accordingly: Sect. 1: What did Marr say?-Sect. 2: Where did his views come from?-Sect. 3: Why did his views gain acceptance?-Sect. 4: Should Marr's image be revised?

\footnotetext{
${ }^{7}$ Bracketed numbers lower than 400 refer to pages in the book under discussion.

${ }^{8}$ In order to save space, Velmezova's references to third sources are not repeated here.

${ }^{9}$ When quoting and citing Marr, Velmezova refers to his Selected Works, not to the original editions, thus preventing the reader from reconstructing the chronological development of Marr's thought $\grave{a}$ la Thomas. This is understandable in view of Velmezova's ambition to present the epistemological core of Marr's views as a timeless structure, and reasonable in view of the enormous bibliographical burden that would be involved in documenting the original sources of all of Marr's statements cited.
} 


\section{What did Marr have to say?}

Velmezova's presentation of Marr's views differs in two respects from earlier analyses.

The New Teaching has primarily been presented as a type of linguistics. In Velmezova's approach, it is treated as the application to language of the unified historical approach to the human sciences that was in vogue after the Revolution.

Most analysts, moreover, used comparative linguistics as the basic reference for describing and characterizing his views, inspired by Marr's own antagonistic rhetoric. When looking at Marr's theories from this vantage point, it is hard to avoid producing a caricature of them: numerous absurdities are immediately exposed and obstruct the view on any underlying consistencies. Velmezova, on the other hand, invokes a Saussurean semiotic conception of language to reveal the essence of the New Teaching.

Velmezova's choices are felicitous. Once they are adopted, the remaining characteristics of the New Teaching follow more or less naturally, producing a more consistent picture of it than has been presented thus far. The core of the New Teaching as identified by Velmezova is presented below.

\subsection{Langage vs. langue}

Characterizing Marr's approach as historical does not imply that Marr investigated the history of languages: it implies that he regarded the history of mankind as an integral evolutionary process (progress) that was governed by universal laws, and considered the evolution of language to be part of it. As Velmezova points out, Marr's research object is Saussurean langage, not langue. To Marr, language was a phenomenon that characterizes, or even defines, mankind and society (200-205). Its origin and development represented what Marr called a universal glottogonic process (50), conditioned by the economic and social progress of mankind at large, which, according to Marr, was itself also conditioned by historical laws (131).

\subsection{Marr's signifiés}

Marr insisted on the two-sidedness of linguistic signs, distinguishing a phonic and a semantic side. Unlike comparative linguistics, which was said to deal with sounds only, the New Teaching regarded signifiés as the focus of linguistic research.

\section{Language and thought}

The laws governing the evolution of humanity and society, in particular labour and its organization, could not be dissociated from those governing human thought. Language and thought (i.e. world outlook, i.e. ideology; cf. 230ff.) had co-developed, or were simply identical (135). The 'linguistic protoplasm' of the New Teaching was 'human thought in its phonic realization' (Marr (1930) 1933, 258).

\section{The law of shared human perception}

Velmezova extensively discusses the general historical law by which Marr intends to account for the development of thought and language: the law of shared human perception. Populations finding themselves at an identical stage of human development perceive the world in the same way (120-121): they think in terms of the same categories and consequently use the same set of signifiés to communicate. 


\section{Linguistic polygenesis}

The assumption that universal laws govern the development of language implies that certain other assumptions about language that are often taken for granted can be regarded as contingent. If language originated in primordial human communities, as Marr assumed, there is no reason to subscribe to a Babelic conception of glottogenesis, i.e. to assume that langage had started off with just one langue: language can simply be assumed to have come about wherever a community had reached a decisive stage in its economic and social development (200ff.).

\section{Manual language}

There are not even reasons to assume that speech, as a vehicle of transmitting thought, originated simultaneously with language. It may be assumed, for example, that speech organs took more time to develop than thought and meaning, while man had other means of communicating them at his disposal. As soon as man started walking on two feet, his hands became available for labour; when the use of tools and the organization of labour produced the beginnings of a social order, calling for communication about the co-ordination of activities, hands were already available. So it need not surprise us that, according to Marr, the rise of vocal language had been preceded by an era in which manual (also referred to as linear, plastic, kinetic, i.e. sign) language had been the only means of communication (123).

\section{Semantic uniformity}

While Marr rejected monogenesis, the law of shared human perception warranted uniformity of the glottogonic process: if the social and economic development of society conditions the development of meaning and thought from their inception all the way to their perfection (201), it is to be expected that, in whatever community the specific economic and social change that is required for language to arise took place, language started off in an identical way, its ulterior development being determined by further social and economic changes.

\section{Marr's semantic laws}

Marr claimed to be discovering the specific semantic laws that governed the origin and development of meaning, both in the past and the future. As Velmezova points out, Marr never properly defined his law concept and used the term in a variety of senses (82-99). Velmezova discusses most of the laws that Marr assumed to be active (106ff.).

The law of semantic differentiation

Even if Marr never explicitly formulated it himself, the law of diffuse semantics or semantic differentiation (177ff.) seems to be his grand law governing the development of semantics. At its inception, language was assumed to comprise just a few diffuse (or non-distinct (159ff.), or polysemic) meanings that were needed in primitive society, while the more specific and diverse meanings that are required in more advanced types of society developed in the course of human evolution: Marrists distinguish between modern polysemy (a single word may have different meanings) and primitive polysemy (no semantic distinction is made between different things if they are designated by the same word) (164-165). 


\section{Marr's little laws}

Marr also used the term law (along with other terms, such as series, bundle and nest) to refer to specific instances of semantic differentiation (177ff.). His work abounds with little laws, such as the one denoted as 'sky' - 'sun', ${ }^{10}$ meaning that, in the course of human progress, the concepts 'sun' and 'sky' sprang from a broader, more polysemic, sky concept that included the sun. Velmezova provides dozens of examples of such specific laws, which were supposed to be triggered by economic or social developments. Many of the specific laws found in Marr's writings contradict each other, but this is not necessarily a consistency problem. Different economic and social conditions may have triggered different little laws. Moreover, not all specific semantic laws seem to belong to the basic core of the New Teaching: little laws represented rather the expected research output, the items that Marr's linguists had to discover by analysing linguistic data.

\section{Marr's pattern laws}

According to Marr, the little laws of semantic differentiation followed certain patterns, which were also called laws (or sometimes formulas or theses, cf. 109) and may be regarded as belonging to the core of the New Teaching. The most important pattern laws treated by Velmezova are the following: ${ }^{11}$

- The whole-part law (180-186) governs what might be described as the emancipation of a part of a whole as a separate concept, as in 'sky' - 'sun': when human thought learned to distinguish between wholes and parts, the sun concept detached itself from 'sky'.

- The law of functional transfer (237-248) governs the shift of a concept when objects functionally replace other objects following an economic innovation: when deer and, later, horses were domesticated to replace dogs as a means of transportation, the concept 'dog' was extended to deer and horses and became obsolete for dogs; this could trigger the little law 'dog' - 'deer' - 'horse'.

- The law of opposites (164-169) determines the rise of two opposed concepts from a diffuse more original concept, as in the case of 'high' - 'deep', having developed from an older, more diffuse, concept (e.g. 'vertical distance'); cf. the conflation of 'lend' and 'borrow' (167) in various languages.

Sometimes different patterns seem to compete. The series 'head' - 'mouth' can be found in Marr's writings alongside 'hand' - 'mouth': the former applies the whole-part law, the latter applies the law of functional transfer (mouths replaced hands as tools for transmitting thought). Marr did not regard such instances of semantic polygenesis as abnormal or undesirable (294).

\footnotetext{
${ }^{10}$ Marr denoted the labels of his meanings between a single high-reversed quotation mark and a right single quotation mark (e.g. 'sky'); Velmezova renders these by single angle quotation marks $(<$ sky $\rangle$ ). Marr's practice gave rise to the term marrovskie kavyčki 'Marrian quotation marks' in Russian typography (where French double angle quotation marks (i.e. « and ») were regularly used for first-level quotation and German low and high double commas (i.e., , and ") were used for embedded quotation). Nowadays the term marrovskie kavyčki refers to English single quotation marks (i.e. ' and'), rather than to Marr's original pair (i.e. 'and'), which is used in the present paper to denote his semantic roots.

${ }^{11}$ Velmezova does not discuss all pattern laws, referring to Pejsikov's longer list (108). One of the laws not covered but referred to elsewhere in her book is the one that rules extension of a concept to objects bearing a formal resemblance to objects already covered, as in Abaev's 'ear (of grain)' - 'spear' (285). This law is also found in Kovalev's $(1928,256)$ enumeration of Marr's laws.
} 


\section{The universal proto-meaning}

Marr often pondered on the issue of the proto-meaning or proto-concept (180ff.). At the dawn of history, had language and thought started off with a single mother of all meanings, from which all other meanings had split off? Marr considered two candidates for this role, 'hand' and 'sky', and talked about a struggle between these concepts (185). The politically correct argument favouring 'hand' is obvious: the creative use of hands as a production tool distinguishes man from animals (cf. Kovalev 1928, 256). The meaning 'hand' turns out to have been the most productive meaning as far as the law of functional transfer is concerned: it has generated, for example, tools and verbs (or even all verbs: 242-245). But Marr had conventionally introduced the label 'sky' as a token of the diffuse, polysemic concept par excellence: it included everything that could not be expressed by manual language-including heaven, god, collectivity, totem, tribe, darkness, etc. (181; see also note 32) - and consequently required vocal expression. This supported the status of 'sky' as the first signifié, or rather the first signifié to correspond to a vocal signifiant. It may be significant that Marr located the origin of vocal language in an environment of shamans and rituals that apparently accompanied organized labour (Thomas 1957, 97), more specifically in what Marr called the 'labour-magic' (trud-magičeskij) process (e.g. Marr (1930) 1933, 257).

The crossing law

Besides differentiation, i.e. the process of diffuse phenomena making way for simple (transparent) phenomena, Marr postulated a second principle for the evolution of meaning, called crossing or hybridization: simple phenomena could be integrated into compound phenomena (212); e.g. 'wind' + 'wind' + 'wind' - 'storm', or 'eye' + 'water' - 'tear' (215). This phenomenon occurred particularly when different populations (collectives, tribes) entered into contact (212). Velmezova regards Marr's crossing law as too vague and immature to pass for a single genuine law (212-216). Nonetheless, Marr was fond of the concept and used various types of crossing (without explicitly distinguishing them).

\subsection{Marr's signifiants}

Whereas most critics extensively discuss Marr's dealings with the formal side of the linguistic sign, Velmezova is rather brief about the position of his signifiants, which she regards as accessory to that of his signifiés.

\section{Vocal differentiation}

The law of semantic differentiation governing the universal glottogonic process is matched by the phenomenon of vocal differentiation (191-192; the term law is not used here). Vocal language started off with a small number of diffuse proto-forms, i.e. robust sound complexes that are characterized by a broad range of non-distinctive variation. These animal sounds were humanized (195) in the course of evolution: refinement of human articulatory capacities facilitated splitting up a fuzzy proto-form into several distinct refined forms and eventually developed the articulate phonemes of modern languages (191). Meanwhile, the vocal repertory also expanded gradually as a result of repeated crossings or mergers of basic forms (roots) into more complex wholes. 


\section{The four proto-roots}

One might expect Marr to have searched for a single proto-signifiant, matching his unique proto-meaning, so that there would be a single specific diffuse sound expressing 'sky'. Velmezova insists, however, that there is no correspondence between the proto-meaning and any proto-form (198). Marr postulated four proto-roots, which he derived from the chantlike sounds that were used in the undifferentiated labour-magic process (Marr (1930) 1933, 258-259). In view of their articulatory instability, he labelled them conventionally after the names of the tribes 'of which they were parts' (195). These are the notorious four elements-sal, ber, ion and roš-, which were used by the Marrists to measure each other's (and prospective graduate students') loyalty and submission, as well as by the Marrists' opponents to ridicule them. ${ }^{12}$ Marr's ontological claims for their labels varied. In some places he assumed an arbitrary, conventional relationship between the labels and the diffuse sound complexes they referred to (198), his use of the labels being comparable to that of the label schwa in regular linguistics. (He sometimes even used the symbols $A, B, C$ and $D$ to denote the four elements, e.g. in Marr (1930) 1933, 259.) Elsewhere, the labels seemed to stand for specific sounds, e.g. when Marr associated German rot 'red' with the element roš (199).

\subsection{Matching signifiants and signifiés}

Marr dissociated the evolution of form from that of meaning. He formulated the regularity (the term law is not used) that linguistic form changes much slower than meaning (148). ${ }^{13}$ As a consequence, linguistic forms contain survivals (remnants, vestiges, relics) of earlier stages of human thought (272), representing information that can be used to detect the specific laws of semantic change.

\section{Palaeontological analysis}

This tenet defined the method of the New Teaching. Marr used biological, geological and archaeological metaphors, speaking of excavations and layers in which relics and fossils could be found (150). Thus, the use of personal forms in impersonal constructions like French il fait chaud 'he makes hot', i.e. 'it is hot' was found to be a survival stemming from a stage in the development of humanity in which forces of nature were personalized: the personal pronoun $i l$ 'he' refers to the sun god (145). Lexical items, too, were said to be composed of roots that provide clues about ancient ways of representing the world: a Georgian word for 'tear' ( $k$ 'urcxali) was said to be a crossing of a root meaning 'eyes' and a root meaning 'water' (215). The articulatory non-distinctness of the roots in the older

\footnotetext{
${ }^{12}$ Marr associated sal with the Sarmatians, ber with the Iberians (and Sumerians, and Cimmerians), ion with the Ionians and roš with the Etruscans (and Pelasgians) (195). In view of the syncretism of 'sky', 'god' and 'collective', it might be suspected that, for each primitive community entering the language era, 'sky' was supposed to match a single signifié. The number of proto-roots, then, simply matched the number of tribes that adopted vocal language independently, i.e. before entering into mutual contact and starting the crossing process, which was supposed to enhance linguistic sophistication. Establishing the number of proto-roots would, then, be an archaeological issue rather than a linguistic one. Apparently, Marr intended such an explanation at one point but forgot about it later (Thomas 1957, 66ff.).

${ }^{13}$ This accounts for, e.g., the late rise of vocal language, or the law of functional transfer: horses could replace dogs without requiring a new signifiant.
} 
stages of language enabled Marr to discover identical roots in forms that are only remotely alike, as in French chien 'dog' and hennir 'neigh' (269).

Since Marr applied his analyses to Saussurean langage, the linguistic material of all languages made up a single collection of disparate items that could travel across the globe individually. Thus, the law 'dog' - 'horse' accounted for Georgian hune 'horse' as well as for Russian kon' 'horse' and Armenian mun 'dog' (239). Marr presented hundreds of such explanations, often involving material from languages that few other linguists and philologists had mastered. The classic example, however, is his connecting the etymologically unrelated German words Hund 'dog' and hundert 'hundred', for which the chain 'dog' 'dog totem' - 'name of the collective' - 'everyone' - 'many' - 'hundred' was established (Alpatov 1991, 47).

Velmezova uses the term etymology for this practice, not without noting the freakishness of this particular brand of etymology (268-269). It might be convenient to retain Marr's term palaeontological analysis here, so as to mark the fact that he was not practising etymology as we know it. Velmezova compares Marr's analytical practice with folk etymology, i.e. establishing semantic links on account of formal resemblance (270). In his approach it is irrelevant whether the forms of Hund and hundert are etymologically related: a postulated relationship between their meanings accounts for their formal resemblance. ${ }^{14}$ Velmezova stresses that, for Marr, the relationship between signifiant and signifié was not arbitrary (268), and qualifies his sign concept as anti-Saussurean: according to Marr, 'meaning depends on linguistic form' (269).

This is where the going gets tough for the epistemologists. What did Marr really think (or want his audience to think)? If meaning is leading in human evolution and develops ahead of linguistic form, which is one of the basic tenets of Marrism, then it cannot at the same time depend on linguistic form. As a way out, Velmezova notes that Marr not only assigned ideological status to the meanings of language but also to its forms (270-271). Since Marr identified ideology with thought (233) and thought with meaning (135), this implies that two different kinds of meaning/thought/ideology were involved in his conception of language: a leading kind of meaning ${ }_{1}$ reflecting contemporary thought on the one hand, and a lagging kind of meaning 2 that reflected more ancient modes of thought and was intimately connected with the form of language on the other. Marr himself did not seem to be interested in this consequence but Abaev worked it out in the 1930s, introducing a distinction between minor or technical semantics (dealing with meaning $_{1}$ ) and major or ideological semantics (dealing with meaning ${ }_{2}$ ) (258-259), thus downgrading Marr's original leading meanings ${ }_{1}$ to a merely technical status.

\section{Stages of linguistic development}

At one point, Marr started believing that the universal glottogonic process could be split up into stages, matching the stages that human economy and society pass through (135). He insisted on identifying the stages and the differences between them in terms of semantic characteristics but only succeeded in doing so for the difference between primitive language and modern language (142). In practice he settled for a stage concept that was based on morphological and syntactic typological characteristics. At one point, he distinguished an isolating, an agglutinating and a flexional stage (140); he also tried to fit in

\footnotetext{
${ }^{14}$ Conversely, Marr rejected established etymological links such as the one between Russian $r a b$ 'slave' and rabota 'labour' in palaeontological analysis, as he did not envisage a plausible semantic relationship between the concepts (Alpatov 1991, 47).
} 
language families as established by comparative linguistics, assigning 'Japhetic' languages (Caucasian, Basque, Hottentot, etc.) to the third stage of human linguistic development and the Indo-European languages that were said to have superseded them to the fourth (133-134). Velmezova mentions the theory of stages but pays relatively little attention to it, apparently regarding it as a marginal component of the New Teaching. ${ }^{15}$

\section{Crossbreeding the perfect language}

Marr's famous tenet of linguistic convergence is a corollary of the law of semantic differentiation and the principle of vocal differentiation on the one hand and the crossing law on the other, which jointly govern the transformation of diffuse, non-distinct entities into differentiated and composite entities. Along with the development of humanity out of a multitude of poor social and economic varieties into a single sophisticated global economy as a result of the joint efforts of the labouring masses, the multitude of diffuse primitive linguistic varieties will progress toward a single integrated global language (200-205), which will be extremely rich and sophisticated, since all the useful semantic distinctions that have been produced even in the most remote communities will be incorporated (Marr 1974, 91-92).

\subsection{Discussion}

These are the assumptions and concepts that Velmezova regards as the core of Marr's doctrine. Marr's phonetic laws and his views on the relationship between class and language are largely left unconsidered. The latter were rather volatile and can hardly be assumed to belong to the epistemological core: at certain junctures, Marr projected class distinctions into periods before the division of labour and postulated the existence of class-bound languages within societies. Even when the New Teaching was about to become the official Marxist doctrine on language, Marr's Marxist allies criticized his conception of social class (e.g. Kovalev 1928, 262ff.).

Velmezova does not systematically discuss an issue that continues to intrigue the present writer, viz. Marr's arguments against comparative linguistics. Of course there were political reasons for rejecting comparative linguistics. As comparative linguistics was agnostic vis$\grave{a}$-vis the origin of language, it had little to offer for anti-creationist propaganda; moreover, most academic comparative linguists were qualitate qua regarded as paid agents of bourgeois nation states. As Thomas suggests, Marr also had personal programmatic motives for rejecting comparative linguistics, as it marginalised the Caucasian languages. On the tactical level, Marr may have been compelled to denounce comparative linguistics because the discipline administered an arsenal of empirical data that seemed to falsify his theories. But a systematic analysis of Marr's reasons for describing comparative linguistics as a pseudo-science from an epistemological point of view might have elucidated this point. The following arguments might be construed.

Epistemologically speaking, it is understandable that Marr did not give any priority to comparative linguistics as its goals were anti-historical: it started working its way back from the present day into history using timeless regularities, such as sound laws, that failed

\footnotetext{
${ }^{15}$ At one point Marr considered invasions of Indo-European speaking barbarians to have produced 'IndoEuropeanization' through crossing (Marr (1920) 1933, 121). Thomas (1957, 117-134) contains an extensive discussion of the difficulties that Marr ran into when trying to fit in his stages into his framework.
} 
to reveal information about the progress of mankind, essential for understanding history as it evolves from the dawn of mankind to its bright future.

Also, it may be suggested, comparativism presupposes the existence of Saussurean langues, not as constructs but as social givens. Marr dissociated himself from the concept of a language as a monolithic mass, preferring to regard it as a cluster of linguistic items, resulting from the crossing of various layers conditioned by external social and economic events (152). To regard each language as a self-sufficient system, governed by its own internal regularities, would create barriers between such clusters of linguistic items and curb the crossing process that guarantees progress toward perfection. Of course the existence of langues in the modern world could not be denied; but their occurrence could be characterized as representing a pattern that was typical for a specific stage of the development of langage. Since the (mainly Indo-European) standard languages of nation states were the most typical varieties of langue as a closed system, they could be regarded as an anti-progressive force, typical for the stage of langage corresponding to the capitalist stage in society. From this vantage point, Marr could live with the perception of langue. But he could not avoid qualifying the Indo-European proto-langue as a fabrication (198): as Kovalev pointed out in his analysis of Marr's views, a kinship of languages is only possible as a product of a shared social order in the past, which cannot be assumed for the earlier stages of human development (Kovalev 1928, 259). Proto-langues therefore just had to be anachronisms, projections of a post-primitive category into the primitive era, based on the unwarranted assumption that langues may change while langage is immutable.

\section{Where did Marr's views come from?}

Although Velmezova's analysis has provided an illuminating insight into Marr's views as an intellectual construct, the synthesis of those views given in the preceding sections is not found there as a separate account. To Velmezova, it is rather a by-product of epistemological analysis.

The goals of epistemological analysis lie beyond the construction of self-sufficient syntheses of individual paradigmatic constructions. Referring to Sériot's criticism of epistemological isolationism (meaning: the study of theories and paradigms without taking the intellectual environment into account), Velmezova has set herself the task of providing a sample of comparative epistemology (40): she investigates the relationships between Marr's tenets and those of other scholars and currents.

Comparative epistemology contributes to answering the question of where Marr's views came from. As earlier analysts surmised, it is not likely that Marr invented all the elements of the New Teaching himself. But Marr's specific intellectual sources are not always evident. Scientists do not always mention the origins of their ideas and sometimes are not even aware of them (81ff.). Conversely, references to other scholars may have served to legitimize one's own ideas and do not necessarily point to real influences. In the type of rhetoric that was required in the 1920s, on the other hand, a new paradigm tended to be defined in terms of the paradigm to be rejected (in Marr's case: comparative linguistics): the alternative paradigm to be proposed should be presented as being different, novel and original, rather than being legitimized by reference to pre-revolutionary intellectual traditions (unless they were Marxist).

\section{Air du temps}

Although the origins of some of Marr's views can be documented, it is in most cases only possible to demonstrate similarities between Marr's ideas and those of other scholars and 
to substantiate the plausibility that Marr had been aware of the latter. Here Velmezova invokes Sériot's concept of air du temps (less frequently air du lieu, 40) as a sociological counterpart of Zeitgeist: scientific conceptions may resemble each other not because the inventors of one influenced the inventors of the other but because both originate in the same intellectual environment (Sériot 1999, 38). The members of a network of intellectuals share a pool of dominant scientific ideas, images, metaphors and preferences from which they draw when producing their discourse, possibly without having a notion of the precise roles of those items in the theories from which they originate. The air du temps of a given period transcends the borders separating disciplines.

Marr had been at the heart of contemporary intellectual life for several decades before developing the New Teaching. Besides being a man of wide reading, he played a broad variety of roles in the intellectual community: he had been an active philologist and archaeologist until the First World War. ${ }^{16}$ After the Revolution, he became a prominent science bureaucrat: he chaired numerous committees in the Academy of Sciences, Leningrad University and various organizations uniting 'intellectual labourers'; he was the director of various research institutes, museums and university departments and of the second most important library of the country. For a while, he was the rector of Leningrad University. ${ }^{17}$ Yet he managed to spend long periods at universities abroad. ${ }^{18} \mathrm{He}$ must have communicated with hundreds of scholars of various disciplines in formal and informal situations. He moved in a large pool of ideas and images, and Velmezova has explored this pool and collected analogies between Marr's views and ideas that can be shown to have been current in his intellectual environment. Space does not permit enumerating all the links that Velmezova documents but the examples given below will suffice to demonstrate the richness of her results.

\subsection{Linguistic evolution in the air du temps}

\section{Social and semantic change}

The idea that the development of society is subject to general laws was widespread in the 19th century, not just among Marxist intellectuals. As regards its application to language, Velmezova relates Marr's thesis that social conditions determine linguistic development to Antoine Meillet's (1866-1936) dictum that social change is the only variable that can account for linguistic change (235); Meillet in turn refers to Émile Durkheim (1858-1917) (235). The 1890s writings of the philologist M. M. Pokrovskij (1868 or 1869-1942) ${ }^{19}$ contain evidence suggesting that the idea of social change producing semantic change flitted through the Russian air du temps: the 'progress of civilization introduces novel concepts and representations in human conscience' (97).

For the use of manual language in primitive societies, Marr is documented as referring to the anthropologist Lucien Lévy-Bruhl (1857-1939) although the latter did not claim that

\footnotetext{
${ }^{16}$ In the decade preceding the First World War, Marr had conducted excavations in Ani, the mediaeval capital of Armenia. During the war, the front line moved over Ani. The devastated site eventually ended up in Turkish territory (Mixankova (1935) 1949, 249).

${ }^{17}$ An enumeration of functions held by Marr in the 1920s is found in Thomas $(1957,87)$.

${ }^{18}$ Marr spent long sabbaticals in various academic settings in Western Europe in 1920-1921 and 19221923 (Thomas 1957, 36); he taught courses of Georgian in Paris in the winter of 1926-1927 and the spring of 1928 (Marr and Brière 1931, xi) and in Turkey in the early 1930s.

${ }^{19}$ M. M. Pokrovskij is not to be confused with the better-known Marxist historian M. N. Pokrovskij (18681932), an ally of Marr's in the 1920s.
} 
it preceded vocal language (123-124). This does not imply, it may be added, that Marr was the first to formulate the manual language hypothesis: at the turn of the century, the Völkerpsychologist Wilhelm Wundt (1832-1920) mentioned the assumption, 'expressed by many anthropologists', that manual language was the real proto-language and had preceded vocal language (Wundt 1911, 144).

\section{The contingency of langues}

Marr refers to the dissident of the comparative method Hugo Schuchardt (1842-1927) for the contingency of langues as self-sufficient closed systems (75). The parallel is interesting because Schuchardt shared Marr's anti-nationalistic sentiments and had done some work on Caucasian languages.

Marr also quoted Schuchardt's statement that every language results from crossing (215). Other links mentioned include Jules Gillièron's (1854-1926) géographie linguistique and Matteo Bartoli's (1873-1946) linguistica spaziale (71). In St. Petersburg itself, as Velmezova points out, Jan Baudouin de Courtenay (1845-1929) had argued in 1901 that every language is mixed (71). The notion itself is, of course, much older and goes back to the Encyclopédistes and probably beyond. All these precedents refer, however, to the crossing of languages: crossing is used as a synonym of mixture (although the term crossing suggests that organic processes occur). Velmezova provides no precedents for Marr's microcrossings on the level of individual meanings and roots, as in, say, his merger of Komi $m u$ 'earth' and Russian zemlja 'earth' into Komi muzem 'earth' (213).

\section{The universal glottogonic process}

Marr's assumption of universal linguistic progress is found in Pokrovskij's work of the 1890s (97). In relation to the stages of Marr's universal glottogonic process, Lévy-Bruhl distinguished prelogical and logical thought (e.g. 133) in a conception of stages of the intellectual development of mankind that can be traced back to Auguste Comte (1798-1857) (139). Marr's morphology and syntax-based distinction of stages resembles a common typology of languages that goes back to Wilhelm von Humboldt (1767-1835) and August Schlegel (1772-1829), who also assumed that these types succeed each other in a fixed order (140ff.). The idea of semantic change ensuing from a revolution is a classic issue that recurs to the Marxist Paul Lafargue (1842-1911) (234) and was revived in the Soviet Union in the 1920s by, e.g., A. M. Seliščev (1884-1942) (261). Of course, such approaches were not all-encompassing like Marr's. They were langue-oriented and did not affect the typological characteristics of a language, the empirical evidence usually being limited to lexical meanings with obvious ideological relevance, such as 'labour', 'poor' or 'saboteur'.

Finally, Marr's thesis that universal laws will eventually cause languages to converge into a world language is paralleled in the anti-Darwinian views of the Leningrad-based biologist L. S. Berg (1876-1950), who in 1922 published a book (Nomogenesis) on the polygenetic character of the origin of organisms and biological convergence. Marr's student O. M. Frejdenberg (1890-1955) almost immediately picked up Berg's model and applied it in literary analysis (307ff.).

\subsection{Semantic change in the air du temps}

The idea that semantic change can be captured in laws is found in various 19th-century sources, including the Völkerpsychologie tradition (88ff.) and the French tradition that 
includes Michel Bréal (1832-1915) (91ff.). Otto Jespersen (1860-1943), too, is shown to have made statements to that effect (295). In Russia, Pokrovskij stated in the early 1890s that 'semasiological phenomena are not arbitrary [...] but governed by specific laws' (97), while 'similar conditions provoke identical consequences' (98). The Vienna-based Marxist Karl Kautsky (1854-1938), incidentally, used practically the same phrases in the 1920s (Kautsky 1929, 273-274). All this confirms the prominence of the idea of semantic laws in the air du temps over a long period. In the 1870s, Baudouin de Courtenay had made a list of 'tendencies' in semantic change that includes some of Marr's laws (94-95).

The law of shared human perception

Velmezova discusses extensively the analogies between Marr and Lévy-Bruhl involving the law of shared human perception (113-158). Although links between the scholars are documented (Marr wrote the preface to the Russian edition of Lévy-Bruhl's Les fonctions mentales dans les sociétés inférieures), it remains uncertain, according to Velmezova, whether Lévy-Bruhl had actually inspired Marr or just served to legitimize Marr's ideas when this was expedient.

The law of semantic differentiation

Velmezova works out the analogies between Marr's law of semantic differentiation and ideas put forward in the 1860s by the polymath Herbert Spencer (1820-1903). Marr never cited Spencer but First Principles (Spencer (1864) 1867) was one of the two books that Marr confessed to having read and reread as an adolescent (208-209). The law of semantic differentiation may be the most important issue dealt with in Velmezova's book; it will be discussed in more detail in Sect. 3.3.

The pattern laws

Marr's whole-part law is thought to have been inspired by Lévy-Bruhl's participation law, which is considered to be essential for primitive thought: in specific types of society, each part of a whole is regarded as equivalent to the whole itself (119). The pattern of semantic change implied by Marr's law of functional transfer was so commonplace that there is no point in identifying a specific source for it; Velmezova mentions Meillet in passing (236). It is interesting to see that Marr's discovery of functional transfer was hailed as a novelty in the adjacent disciplines. The archaeologist S. I. Rudenko (1885-1969), for example, used it to explain the presence of deer masks on buried horses (254). Precursors can also be found for Marr's law of the opposites, which at first glance represents one of the most curious types of linguistic change. Velmezova refers to the Czech-born Russian-based linguist V. I. Sercl (1843-1906) ${ }^{20}$ and the German egyptologist Carl Abel (1837-1906), and ultimately to Georg Wilhelm Friedrich Hegel's (1770-1831) dialectic $(206,208)$, although the pattern that the law of opposites captures looks like the converse of Hegelian synthesis. Sigmund Freud's (1856-1939) adoption of the law of opposites in the early 20th century testifies to its prominence in the air du temps (173-175).

${ }^{20} \breve{S}$ ercl had also expressed ideas about the transition from manual to vocal language (Xramov 2008, 73ff.). 


\subsection{The form of language in the air du temps}

The idea of the 'humanization of language' through vocal differentiation of animal sounds, and even its phrasing (195), are found in Baudouin de Courtenay's work written in the 1890s. Baudouin regarded, like Marr, the development from diffuse sounds into articulated phonemes as a product of human progress (193-195). Marr's use of Baudouin's term phoneme may also be regarded as indicative of the air du temps in 1920s Petrograd and Leningrad.

\section{Survivals}

The notion that meaning and form develop at different speeds, thus producing survivals on the signifiant side, has always been present in reflection on language. One of the examples given is Charles Bally's (1865-1947) qualification of grammatical gender in such languages as French as a remnant of a pre-rational past (149). The concept of survival itself goes back to social evolution theory (Eduard Burnett Tylor (1832-1917) was its champion). It may be added that it was a household concept of 1920s Marxists, busy as they were eliminating the survivals of capitalism in the people's minds.

\section{Two types of signifié}

Marr's notion that the forms of language have their own ideology turns out to have been generally accepted in various currents of 1920s Russian Marxist and non-Marxist thought, such as Imjaslavie ('Glorification of the Name'), which included P. A. Florenskij (18821937) and A. F. Losev (1893-1988) and whose theological position is epitomized by the formula 'the name of God is God himself' (273). The conclusion, drawn by Abaev, that two kinds of meaning are to be distinguished, goes back to the Ukrainian-born linguist A. A. Potebnja's (1835-1891) distinction between the inner and the outer form of a word (262-263): Potebnja's forms are the modern linguist's meanings. Abaev himself refers to Humboldt's corresponding distinction, noting as the important difference between the Humboldtian and Marrist conceptions that Humboldt turns each national language into an autonomous, separate, unique, impervious universe, whereas ideological semantics, while distinguishing languages, also brings distant languages together.

\subsection{Discussion}

Velmezova adduces many more analogies between Marr's views and views expressed earlier by other scholars. In doing so, she does not confine herself to signalling convergence but also analyses the differences. The picture she presents indicates that few of the tenets of the New Teaching were original: nearly all of them can be shown to have been present in Marr's academic environment. The only tenets for which Velmezova provides no precursors are Marr's anti-Babelic stance on glottogenesis and his identification of the single universal proto-meaning and the four proto-roots.

But even here, Marr may turn out to have been a child of his time, rather than a maverick in a world dominated by comparative linguists. Throughout the second half of the 19th century, the idea of linguistic polygenesis had been rather respectable among biologists, social scientists and anthropological linguists. The views of the American linguist John Wesley Powell (1834-1902), for example, were quite similar to Marr's: mankind was distributed throughout the habitable earth anterior to the development of organized speech, 
so language and other common human institutions had to be accounted for by polygenesis and identical evolution through fixed stages; these could be investigated by studying the languages of tribes in the lower states of culture (Powell 1881, 80, cited by Murray 1994, 40-41).

Theories on glottogenesis were in fact so common that Otto Jespersen could present a typology of them in the early 1920s, distinguishing the bow-wow theory (language developed from onomatopoeia), the pooh-pooh theory (language developed from instinctive interjections), the ding-dong theory (language exploited some perceptible isomorphism between objects and sounds) and the yo-he-ho theory, according to which sounds that were produced as a by-product of muscular effort turned into vocal language in situations requiring collective co-ordination of such efforts (Jespersen 1922, 413-416).

Marr can be shown to have been aware of such theories. Lazarus Geiger (1829-1870) and Ludwig Noiré (1829-1889) had discussed the evolutionary origin of language in great detail (e.g. Geiger 1868, 1872; Noiré 1877, 1880) and reviewed many of the issues raised by Marr, including the onomatopoeic vs. ritual origin of language, the key role of the hand, the question of whether language started with verbs or nouns, and even the identification of the specific proto-roots and the proto-meaning (e.g. 'digging'; cf. Noiré 1877, 372). Their yo-he-ho type of approach obviously appealed to Marxists as it connected the origin of language with that of society. Kautsky cited their views extensively in his Materialistic conception of history $(1929$, 587-608). Marr himself cited Geiger and Noiré (e.g. Marr $1974,260)^{21}$ and mentioned that such prominent ideologists as G. V. Plexanov (18561918), A. A. Bogdanov (1873-1928) and N. I. Buxarin (1888-1938) had adopted Noiré's vision on the origin of language (Marr 1974, 234).

There is therefore considerable evidence that, as far as the origin of language is concerned, Marr was quite in tune with the air du temps. ${ }^{22}$ A future exploration of the epistemological networks for glottogonic theories might produce an interesting supplement to the picture presented in Velmezova's book.

\section{Why did Marr's views gain acceptance?}

Most analysts explain the increasing popularity of the New Teaching in the 1920s and its dominant position since 1929 by factors that are external to linguistics, such as political developments and the Marrists' opportunism (31). It is Velmezova's intention to show that deeper factors account for the rise and dominance of Marrism. She argues that competing approaches that also claimed to be Marxist, such as the one championed by the Moscow-based Jazykfront (or Jazykofront), did not succeed (60). The ideological margins of Marxism had even tolerated the retention of comparative linguistics, as illustrated by its restoration by Stalin in 1950. Velmezova, therefore, explores an intrinsic, epistemological explanation for the success of the New Teaching in the 1920s and 1930s.

Here, too, the air du temps is invoked. For a theory to be successful, two conditions must be met. On the one hand, it should supply a need: the intellectual circles that matter

\footnotetext{
${ }^{21}$ Marr never cited Kautsky, who had sojourned in Georgia at the invitation of the Georgian government in 1920-1921 and had published a book on the country, with a chapter on its occupation by the Bolsheviks in 1921, after which Lenin had branded him a renegade. Marr's Marxist opponents, on the other hand, eagerly exposed the parallels between Marr's and Kautsky's views (e.g. Danilov 1929, 51).

${ }^{22}$ Jakobson, in his comments on Trubetzkoy's letter cited in note 5, mentions a non-Marxist Russian predecessor of Marr: in a book published in 1897, D. P. Martynov advanced the idea that all words in all languages derive from a root meaning 'eat' (Trubetzkoy 1924, 74).
} 
should be waiting for it. On the other hand, it should have a familiar quality: its components should appeal to beliefs and images that are prevalent in the relevant circles. Velmezova's book deals with both aspects.

\subsection{The crisis of comparative linguistics}

Velmezova points to the circumstance that, in the early 20th century, linguistics was perceived to be undergoing a paradigmatic crisis (65). The comparative method, with its focus on sound laws and dependence on ancient written sources, had reached fulfilment (68). The basic structure of the major linguistic families had been established and the method was now thought to run up against its limitations, which caused a crisis of the subject of research ("crise du matériau de recherche" $68 \mathrm{ff}$.). The comparative method did not seem fit to establish kinship relations involving a greater time depth and failed to account for residual languages (like those found in the Caucasus), for mixed languages (such as creoles), or for sociolinguistic patterns where it is hard to draw a line between different languages. Moreover, some levels of language, such as semantics, did not seem to be amenable to the comparative method.

Although Velmezova mainly cites Soviet linguists who insisted on the crisis, she notes that dissidents of the comparative method could also be found elsewhere. She links the Soviet linguists' uneasiness with the comparative paradigm to the rise of the Prague School and structuralism and with such globalist tendencies as led to the organization of the First International Congress of Linguists in 1928. All this seems to suggest that the crisis was in the air du temps, linguists all over Europe were trying to find novel approaches, dealing with new material and problems (67). Marr's theories could supply this need for fresh concepts.

\section{Discussion}

It may be agreed that there was a crise du materiau, in the sense that comparative linguistics had picked most of the low-hanging fruit. The method could be said to be facing the law of diminishing returns, requiring a higher level of sophistication and training to solve the remaining minute details. But, as history has shown, the comparative method had not nearly exhausted its potential. It is therefore questionable whether the crisis was really of an epistemological nature.

In fact, Velmezova's book contains a quote from Marr in which he observes that we are not dealing with a crisis of Indo-European linguistics but rather with the difficult position in which the scholars belonging to that school find themselves (63). Marr's analysis is plausible. Until the First World War, linguistics and philology had been associated with the nation state projects of Europe. In the perception of the public at large, they had served to furnish pedigrees to both the great nations and the nations that were striving for independence. As far as this audience was concerned, comparative linguistics had more or less completed its mission after the war. Every nation had found its place on a family tree; the remaining unsolved puzzles in the trees would not change the general picture and the few residual languages were of minor political import.

Matters were even worse for Russian linguists. The war and the Revolution had deprived many of them of their research facilities and separated them from their natural intellectual 
habitat, compelling them to explore new directions. ${ }^{23}$ This may be a factor in explaining the globalization of the uprooted emigrés toward structuralism.

In the Soviet Union itself, meanwhile, the nation state institutions had lost all of their credit after the Revolution, which created the need for an academic practice in linguistics that explicitly dissociated itself from it. The humanities went through a series of drastic reorganizations, in which Marr played a leading role. In 1919, being the dean of the Faculty of Eastern Studies, he initiated its merger into the Faculty of Social Sciences (which eventually comprised all the disciplines of Leningrad University except the natural sciences and the medical school). The new faculty, of which Marr became the first dean, included an ethnological-linguistic department (Šilov 1969a, 212). In the same year Marr founded the Russian Academy of the History of Material Culture (RAIMK, later GAIMK), creating material culture as the Marxist substitute for archaeology. ${ }^{24}$ Since these institutional structures seem to antedate the introduction of theoretical elements from ethnology and material culture (such as periodization, cf. 153) into Marr's published linguistic framework, the possibility that Marr developed his theories as an epistemological response (or even corollary) to institutional imperatives, rather than as a way out of an intrinsically epistemological crisis, merits being investigated. The idea would be in line with Marr's own paradigm: if social and economical environmental factors condition the development of thought and language, why should reflection on language be exempt from them?

\subsection{Marrism and holism}

Velmezova also explores the second condition for success: the conscious or subconscious familiarity of Marr's ideas for his audience. She points to a particular aspect of the air $d u$ temps that may have contributed to their acceptance: the penchant of 1920s intellectuals for holistic theories (331ff.), which she illustrates with the Eurasian trend in Trubetzkoy's and Jakobson's work (336), with the Imjaslavcy, who referred in turn to the philosopher V. S. Solov'ev (1853-1900) and his concept of 'omniunity' (vseedinstvo) (337ff.), with the ecological ideas of the geologist and philosopher V. I. Vernadskij (1863-1906) ${ }^{25}(333-335)$ and, finally, with the launching of holism by General Jan Christiaan Smuts (1870-1950) $(338-339)$.

\section{Discussion}

As Smuts introduced holism only in 1926, in his book Holism and Evolution, its characteristics must have been in the air du temps before it was defined. Now which characteristics of this holism avant la lettre are relevant to the reception of Marrism in the 1920s?

The features shared by Marrism and holism include the application of the laws of one discipline to another discipline. Marr regularly insisted on breaking down the barriers between linguistics and other disciplines (e.g. 257), and Velmezova repeatedly remarks that the key to understanding Marrism lies outside linguistics (e.g. 340). In fact, most of the tenets of the New Teaching were more familiar in adjacent disciplines, such as archaeology, ethnology, history, biology and philosophy, than in contemporary linguistics. This may

\footnotetext{
${ }^{23}$ Baudouin de Courtenay, for example, had lost all of his material. This 'nearly completely paralysed [his] scientific activity' (Baudouin de Courtenay 1929, 186).

${ }^{24}$ The Faculty of Linguistics and Material Culture (Marr's famous Jamfak) was created in 1925 (Šilov 1969b, 227).

${ }^{25}$ Vernadskij is credited with having popularized the terms and concepts of biosphere and noosphere.
} 
have contributed to their success: by appealing to principles that were generally accepted in other disciplines, linguistics became acceptable to the non-linguists who decided on its future. ${ }^{26}$

But, as Velmezova shows, the holist appeal of Marr's theories also functions on a deeper level. The idea underlying holism is that the laws that govern the behaviour of aggregated phenomena (wholes) cannot be derived from those governing the behaviour of their component phenomena (339): the whole is more than its parts. Thus, evolution proved that laws governing organisms cannot be derived from those governing inorganic matter (e.g. the second law of thermodynamics does not explain the behaviour of living matter, cf. Smuts 1926, 156ff.); the laws governing human behaviour do not simply result from the laws governing the behaviour of organisms, etc. (At the same time, there are general laws governing the behaviour of wholes, irrespective of the type of phenomenon of which they are aggregates: the mass behaviour of humans resembles the mass behaviour of atoms.)

This aspect of holism was certainly in the air du temps. The Revolution seemed to prove that historical laws governing mass behaviour overrode those governing individual human acts. A 1920s Soviet Marxist is likely to have acclaimed a linguist asserting that the laws determining the grand narrative of mankind applied to language as well as to other human institutions. According to Velmezova, semantics was viewed as the force tierce, the integrating force that guided the evolution of language as a whole. Comparative linguistics did not have this holist appeal: it only dealt with solving ahistoric formal puzzles that were detached from social reality (329-330).

\subsection{Semantic differentiation as a holist law}

Marr's central law of semantic differentiation is likely to have had a particular appeal to holists avant la lettre. Marr applied the idea of diffuse phenomena developing into distinct and articulated (i.e. resulting from crossing) phenomena both to the evolution of meaning and to the evolution of form. As pointed out by Desnickaja (1951, 48ff.), the underlying general principle governing this development had been formulated by Herbert Spencer, whose authority was hardly second to Charles Darwin's in the second half of the 19th century. A homogeneous aggregate in a non-homogeneous environment, according to Spencer, is bound to lose its homogeneity as its different parts are exposed to different forces in its environment; this induces its disaggregation into discrete (differentiated) phenomena (207) and their subsequent integration into compound aggregates (Spencer (1864) 1867, 329-330). A homogeneous mass of protoplasm, for example, differentiates as its outside layers undergo the impact of its heterogeneous environment. "The development of formless protoplasm into an embryo is a specialization of parts, the definiteness of which increases only as fast as their combination increases" (Spencer (1864) 1867, 135).

Spencer applied his principle to inorganic, organic and super-organic (i.e. social) evolution, including language, folklore and art, and literature (cf. Spencer (1864) 1867, 347-359), which characterizes it as holist avant la lettre. The principle must have had a powerful appeal anyway, as it echoed numerous cosmogonies, including the teleological interpretation of the Marxist laws of history. ${ }^{27}$ Baudouin de Courtenay had taken it over

\footnotetext{
${ }^{26}$ Linguists active in the 1930s later described the New Teaching as a buffer shielding them from their hostile environment (Alpatov 1991, 112ff.).

${ }^{27}$ Although Spencer, who was credited with coining the phrase 'survival of the fittest', explicitly dissociated himself from Marxism, 19th-century Marxists strove to annex him, cf. Ferri ((1895) 1917, 159ff.).
} 
to account for the evolutionary development of the phoneme out of diffuse animal sounds. The influential scholar A. A. Veselovskij (1838-1906) had applied Spencer's principle to literature, exploring the differentiation of genres in the course of history (208-211). So Marr's discourse on semantic differentiation of diffuse 'linguistic protoplasm' and the crossing of the resulting discrete units must have sounded familiar to scientists from the neighbouring disciplines who attended his frequent academic addresses (such as Marr (1930) 1933, 258).

\section{Should Marr's image be revised?}

It will be clear by now that Velmezova provides relevant and inspiring contributions to all of the issues that have been discussed so far. ${ }^{28}$ The last question to be discussed is whether Velmezova's approach yields new viewpoints that will have to be taken into account by historians assessing Marr's role in linguistics and science at large.

Marr has been branded a solitary visionary, a cynical opportunist, an ambitious charlatan, a naive idealist and a mental patient. Velmezova presents a novel picture. By reducing Marrism to what seems to be its intellectual quintessence and by staging Marr in a rich and varied academic setting, she styles him as an opinion leader of the Soviet intelligentsia, a widely-read scholar who was aware of what was going on in European intellectual life. Is this new image merely to be added to the existing ones or should it replace some or all of them?

It seems that the deviating picture that Velmezova produces is due to her methodological choices. The method of epistemological analysis suggests that the quintessential New Teaching actually existed. But the consistent intellectual framework that Velmezova provides may represent a construct made by an intelligent reader rather than a reconstruction of Marr's actual views at any given point in time: it was produced by stripping Marr's arguments of his excessive digressions and overkill of exotic material, but also by downplaying tenets that do not fit in well, such as his phonetics, his theory of stages or his theory of classes.

This problem, however, which is in a way analogous to that of the ontological status of the structure of a language in synchronic linguistics, may not be the most essential methodological issue under discussion. A final methodological note will deal instead with Velmezova's use of the concepts of air du temps and epistemological neutrality.

\subsection{The air du temps as a diffuse concept}

It may be argued that the concept of air du temps, as employed in the book, is too broad to provide fully satisfactory explanations for the interaction between Marr and his academic environment. When used to account for the rise of Marrism in the 1920, it implies that Soviet intellectuals (and even intellectuals tout court, as Velmezova does not systematically distinguish Russian, Soviet and European intellectuals) are dealt with as a single, relatively diffuse group. Since Marr's views also met with vehement criticism and articulated resistance on the part of both linguists and non-linguists, ${ }^{29}$ it is expedient to

\footnotetext{
${ }^{28}$ Velmezova contributes in passing to the solution of a few puzzles, such as Stalin's reasons for rejecting the New Teaching in 1950: according to Velmezova, Marr's ideological semantics, as worked out by Abaev, was no longer compatible with Stalin's foreign policies (288); but see note 34 .

${ }^{29}$ Cf., e.g., L'Hermitte (1987), passim, or Alpatov (1991), passim, for the various discussions accompanying the rise of the New Teaching.
} 
explore the epistemological profiles of the various subgroups of intellectuals that were amenable or immune to the New Teaching. If Marrism was not acclaimed by all Marxists, and if the group acclaiming it did not just comprise Marxists, as Velmezova insists, then how did the groups that acclaimed it further its dominant position? The concept of air du temps seems to be too undifferentiated to be very helpful in answering this question.

\subsection{The air du temps as a narrow concept}

It may be argued that the question raised above is beyond the scope of comparative epistemology and must be referred to sociology of science or institutional history. At the same time, however, the air du temps concept seems to be on the narrow side. In tracking down Marr's sources of inspiration, we may wonder why the search should be limited to his scholarly intercourse. It cannot be excluded off-hand that Marr's theories were inspired by ideas and observations that circulated in non-academic regions of his environment, which may also have furthered their acceptance.

\section{Marr as a Caucasian intellectual}

Marr's Caucasian connection, for example, received little attention in Velmezova's book, even though the New Teaching started out, as the Japhetic Theory, dealing with a Caucasian problem. This circumstance may have epistemological implications.

Kuipers (1960) observes that the structure of a linguistic theory may have been prompted by properties of the languages dealt with by the linguists developing it. Comparative linguistics was developed by students of languages with histories characterized by geographical expansion followed by isolation of individual branches and by long-standing written traditions, as a result of which the fuzziness produced by dialectal variation within branches was limited, making genealogical tree structures stand out clearly. Structuralist phonology, in turn, was developed by students of Russian, which possesses sizeable series of minimal pairs differing by one distinctive feature only, making such features stand out clearly. Finally, the poor morphology of English, entailing reliance on the relative position of words in sentences for the correct interpretation of text, may have occasioned the rise of generative syntax in environments where written English was the language under investigation (Kuipers 1960, 21-22).

Likewise, Kuipers suggests, Marr's theories may have been prompted by the characteristics of the languages of the Caucasus. While the formal material of these languages resisted the establishment of genetic relationships by state-of-the-art comparative linguistics, they shared numerous phonological and semantic Spachbund features, prompting the insight that linguistic crossing and convergence are fundamental processes, with Armenian as a particularly tempting example (Kuipers 1960, 23). Even Marr's proto-meanings and proto-roots look more plausible when considered from a Caucasian vantage point: in Circassian, according to Kuipers, most of the lexicon can be reduced to combinations of only two hundred basic roots consisting of only one or two phonemes. The word for 'tear' combines the roots meaning 'eye' and 'water'; 'saliva' is 'mouth' plus 'water'; 'beard' is 'mouth' plus 'tail', etc. Some of the roots are so similar in both form and meaning that they suggest the impression of having resulted from the differentiation of a more diffuse concept matching a more diffuse root: Circassian 'heart' is $g u$, while 'core' is $k u$ (Kuipers 1960, 24).

It thus seems that Caucasian linguistic aspects cannot be ignored in a definitive analysis of the origins and reception of the New Teaching. Such an analysis may continue to remain 
a desideratum: few historians of linguistics possess the specialized linguistic knowledge required to deal with those aspects, while specialists from the Caucasian region tend to approach Marr's linguistics less critically, preferring to assess his merits by his philological and archaeological achievements and their positive or negative implications for the local cultural self-image.

Checking Marr's Caucasian connection, on the other hand, should not be limited to linguistic aspects. As Marr hardly distinguished language, folklore and history, mythological aspects may also have to be involved, such as the prominent position of Japhet ${ }^{30}$ and Prometheus $^{31}$ in Caucasian folklore, as well as national or regional messianism. ${ }^{32}$ It may be noted, furthermore, that the demise of Marrism in 1950 was, like its rise, initiated in the Caucasus. ${ }^{33}$

\subsection{The air du temps vs. epistemological neutrality}

More generally, employing Seriot's air du temps as a concept explaining the origin of Marr's theories while restricting its scope to his academic or intellectual context does not seem to be compatible with Auroux's imperative of epistemological neutrality. If a historian of science must refrain from imposing a preliminary distinction between scientific and non-scientific elements in his matériau de recherche, it is hardly consistent to employ a distinction between intellectual and non-intellectual environments in accounting for its

\footnotetext{
${ }^{30} \mathrm{Cf}$. Marr's adoption of the term Japhetic, after Noah's second son Japheth, but also associated, through Marr's phonetic laws, with the Titan (or proto-god) Japetos, who was defeated by the 'Indo-European' Zeus. Japetos' son Prometheus is a mythical hero in all Caucasian traditions, whose folklorists seem to be reluctant to discuss the possibility that such myths may have Hellenic origins (cf. Čokaev 1992).
}

${ }^{31}$ Marr used Prometheus to split off 'fire' from 'sky'; 'fire' in turn was said to yield 'reason' (cf. Marr (1920) 1933, 120). Marr's student Abaev, an Ossetian (i.e. speaker of an Indo-European language) born in Georgia (in Kobi, i.e. outside present-day Ossetia), when converting the Indo-European family into a Marrian linguistic stage, proposed to coin the term Promethean for this stage, as the Indo-Europeans embodied Prometheus' 'creative spirit, energy and enterprise' (Abaev 1926, 207).

${ }^{32}$ As L. Broers reports (Tolerance and mission: strands of messianic thought in Georgian nationalism. Unpublished paper, presented at the Seventh Annual Convention of the Association for the Study of Nationalities 2002; Panel: Ethnicity and nationalism in the Caucasus), the first post-Soviet president of Georgia, Zviad Gamsaxurdia (1939-1993), a champion of Georgian messianism, made extensive use of Marr's theory, finding in it evidence of a Japhetic civilization once stretching from the Pyrenees to India and presently reduced to the Caucasus as a result of the rise of Indo-Europeanism. Gamsaxurdia described the Indo-Europeans as imperialists, invaders and suppressors, even picturing them as exercising power over Japhetic plebs in ancient Rome, and the Georgians as a chosen nation with the mission of saving what was left of the Japhetides in the Caucasus. Even the eagle that eats out Prometheus' heart daily was identified as the "symbol of Indo-European might" (Broers, 13-15). The question is whether, or to what extent, Marr inspired this messianistic air du lieu or had been inspired by it.

${ }^{33}$ Stalin sustained a special interest in Caucasian affairs. The demise of Marrism started when the Georgian linguist Arnold Čikobava (1898-1985) was flown to Moscow to clarify the situation in linguistics to Stalin, the local party chief K'andid Čark'viani (1906 or 1907-1994) having acted as an intermediary (Čikobava 1985). To the present writer's knowledge, the possibility that Stalin decided against Marr on account of Caucasian political considerations has not yet been investigated. Yet this possibility cannot be excluded. Although Gamsaxurdia exploited Marr's myths to buttress Georgian supremacy, Marrism was primarily intended as a pan-Caucasian ideology. Marr's conversion from a Georgian nationalist into a regional cosmopolite during his archaeological work in Ani (Marr (1930) 1933, 271) was transparent in his staffing policy: his institute employed young linguists from all over the Caucasus. The deportation of entire Caucasian nations in the 1940s, on the other hand, reveals the presence of intra-Caucasian ethnic preferences on Stalin's part. They reflect Stalin's policy to align populations and their languages and histories with administrative boundaries. 
epistemological relationships and leave the non-intellectual ones out of consideration. If all of Marr's insights must be taken seriously as an object of research simply because Marr advertised them as scientific, it follows that his complete environment should be checked when accounting for their origins and acceptance, including science and university politics, Marr's biography ${ }^{34}$ and contemporary art. ${ }^{35}$

\subsection{Conclusion}

All this does not of course alter the fact that the epistemological method has proven to be a productive tool in producing facts and solving puzzles connected with the Marr phenomenon, making the book a vital resting place for students of Soviet sociolinguistics. Velmezova has filled a niche in the literature on Marr and Marrism but, with the possible exception of the assumption that Marr was mentally ill, which she successfully argues to be irrelevant (40) and implausible (42-44), the new facts that have been brought up are not likely to dispel the existing notions of Marr: to many linguists and historians of linguistics, the serious pursuit of conclusive evidence is an essential defining property of science. To them, no degree of scholarship, elegance or consistency that may turn out to have characterized the New Teaching can outweigh Marr's overt contempt for empirical matters.

Open Access This article is distributed under the terms of the Creative Commons Attribution Noncommercial License which permits any noncommercial use, distribution, and reproduction in any medium, provided the original author(s) and source are credited.

\section{References $^{36}$}

Abaev, V. I. (1926). Dva slova o terminax. Jafetičeskij sbornik, 4, 205-207.

Alpatov, V. M. (1991). Istorija odnogo mifa. Marr i marrizm. Moskva.

Aptekar', V. B. (1929). Šag nazad. I. Meščaninova Vvedenie v jafetidologiju I.L. Ja.Z.V. “Priboj”, Leningrad. 1929. Novyj vostok, 26-27, 261-269.

\footnotetext{
${ }^{34}$ Marr's biography contains several elements with imaginable epistemological implications. His father was a Scotsman, i.e. a Celt, a semi-Indo-Europeanized Japhetid, who had lost his language. Speaking only English and French, he communicated with Marr's Georgian mother in what Marr described as a crossing (Marr (1927) 1933, 6). Being in his eighties when he married Marr's mother, he died when Marr was nine (Mixankova (1935) 1949, 7-9). Marr's mother was a young girl from Guria, the dialect of which had infiltrated Marr's grammar of Georgian (Vogt 1933, 144-145), while Marr had discovered its Arcadic counterpart in the Pyrenees (Marr (1928) 1937). Marr married a scion of a family of orientalists. His son, the orientalist Ju. N. Marr (1893-1935), was active in a Tbilisi-based group called Abstruse Futurists ' $41^{\circ}$, during the Menshevist Georgian republic, and is claimed to have been the first futurist poet to graphically mix languages with 'fundamentally different alphabets' (Nikol'skaja 1995, 11). His youngest son was killed on the Southern Front as a recruit of the Reds (Mixankova (1935) $1949^{3}$, 285). Marr's grandson was deaf-mute (Oldenbourg 1977, 15) and must have learned sign language in the early 1920s.

${ }^{35}$ Marr himself proposed to merge art and science (Marr (1931) 1934, 111) and hardly seemed to distinguish them. In the first issue of his Japhetic Journal, he characterized his theory as an embarkation on a poorly equipped ship for a voyage on a boundless ocean, without havens on the other shore. The other shore did not even exist: it would only serve to rest and there would be no rest for those scientists who had abandoned the safe havens created by [comparativist] tradition (Marr 1922, i).

${ }^{36}$ Where two years are given, bibliographical information and page number refer to the last year mentioned; the first year indicates when the item was first published. Where three years are given, the first year indicates when the text was written.
} 
Aptekar', V. B. (Ed.) (1933). Voprosy jazyka v osveščenii jafetičeskoj teorii. Izbrannye otryvki iz rabot akad. N. Ja. Marra. Leningrad.

Baudouin de Courtenay, J. (1929). Einfluss der Sprache auf Weltanschauung und Stimmung. Prace filologiczne, 14, 185-256.

Bjørnflaten, J. I. (1982). Marr og språkvitenskapen i Sovjetunionen. Bidrag til den Sovjetiske språkvitenskaps historie (Tromsø-studier i språkvitenskap, 5). Oslo.

Borbé, T. (1974). Vorwort. In T. Borbé (Ed.), Kritik der marxistischen Sprachtheorie N. Ja. Marr's (Skripten Linguistik und Kommunikationswissenschaft, 8) (p. 3). Kronberg.

Čikobava, A. S. (1985). Kogda i kak èto bylo. Ežegodnik iberijsko-kavkazskogo jazykoznanija, 12, 9-23.

Čokaev, K. Z. (1992). Ešče raz o Prometee v čečenskom fol'klore. Px'armat: Noxčijn fol'klor ètnografi, 2 , $16-18$ and 22-25.

Danilov, G. K. (1929). Marksistskij metod v leksikologii. Russkij jazyk v sovetskoj škole, 6, 48-62.

Desnickaja, A. V. (1951). O roli antimarksistskoj teorii proisxoždenija jazyka v obščej sisteme vzgljadov N. Ja. Marra. In V. V. Vinogradov \& B. A. Serebrennikov (Eds.), Protiv vul'garizacii i izvraščenija marksizma v jazykoznanii. Sbornik statej. Čast’ 1 (pp. 26-59). Moskva.

D’jakonov, I. M. (1995). Kniga vospominanij. Sankt-Peterburg.

Ellis, J., \& Davies, R. W. (1951). The crisis in Soviet linguistics. Soviet Studies, 2(3), 209-264.

Ferri, E. (1895) 1917. Socialism and modern science (Darwin, Spencer, Marx). Chicago.

Frejdenberg, O. M. 1937 (1988) 2001. Vospominanija o N. Ja. Marre. In V. H. Bazylev \& V. P. Neroznak (Eds.), Sumerki lingvistiki. Iz istorii otečestvennogo jazykoznanija (pp. 425-443). Moskva.

Gamkrelidze, T. V. (1989). The "unconscious" and the problem of isomorphism between the genetic code and semiotic systems. Folia Linguistica, 23, 1-5.

Geiger, L. (1868). Ursprung und Entwickelung der menschlichen Sprache und Vernunft (Band 1). Stuttgart. Geiger, L. (1872). Ursprung und Entwickelung der menschlichen Sprache und Vernunft (Band 2). Stuttgart. Jespersen, O. (1922). Language. Its nature, development and origin. London.

Kautsky, K. (1929). Die materialistische Geschichtsauffassung, 1: Natur und Gesellschaft. Berlin.

Kovalev, S. I. (1928). Jafetičeskaja teorija i marksizm. Doklad i prenija, sostojavšiesja v Istoričeskoj sekcii Instituta marksizma 25 janvarja i 1 fevralja 1928 g. In V. Belenko, S. Gonikman, G. Zajdel', B. Pozern \& A. Stoljarov (Eds.), Problemy marksizma. Stat'i i issledovanija (pp. 243-297). Leningrad.

Kuipers, A. H. (1960). Aspecten van de twintigste-eeuwse Russische linguistiek. Den Haag.

L'Hermitte, R. (1987). Marr, marrisme, marristes. Une page de l'histoire de la linguistique soviétique (Cultures et Sociétés de l'Est, 8). Paris.

Marcellesi, J.-B. (Ed.) (1977). Langage et classes sociales. Le marrisme (Langages, 46). Paris.

Marr, N. Ja. (1920) 1933. Jafetičeskij Kavkaz i tretij ètničeskij èlement v sozidanii sredizemnomorskoj kul'tury. In V. B. Aptekar' (Ed.), N. Ja. Marr. Etapy razvitija jafetičeskoj teorii (Izbrannye raboty, 1) (pp. 79-124). Leningrad.

Marr, N. Ja. (1922). Predislovie. Jafetičeskij sbornik, 1, i-iv.

Marr, N. Ja. (1927) 1933. Avtobiografija N. Ja. Marra. In V. B. Aptekar' (Ed.), N. Ja. Marr. Etapy razvitija jafetičeskoj teorii (Izbrannye raboty, 1) (pp. 6-13). Leningrad.

Marr, N. Ja. (1927) 1937. Gottentoty-sredizemnomorcy. In I. A. Orbeli (Ed.), N. Ja. Marr. Osnovnye voprosy istorii jazyka (Izbrannye raboty, 4) (pp. 115-124). Leningrad.

Marr, N. Ja. (1928) 1937. Iz Pirenejskoj Gurii (K voprosu o metode). In I. A. Orbeli (Ed.), N. Ja. Marr. Osnovnye voprosy istorii jazyka (Izbrannye raboty, 4) (pp. 3-52). Leningrad.

Marr, N. Ja. (1930) 1933. Jafetidologija v Leningradskom gosudarstvennom universitete. In V. B. Aptekar' (Ed.), N. Ja. Marr. Etapy razvitija jafetičeskoj teorii (Izbrannye raboty, 1) (pp. 254-272). Leningrad.

Marr, N. Ja. (1931) 1934. Jazyk i myšlenie. In F. V. Kiparisov (Ed.), N. Ja Marr, Jazyk i obščestvo (Izbrannye raboty, 3) (podgotovlen k pečati V. B. Aptekarem) (pp. 90-122). Leningrad.

Marr, N. Ja. (1974). Die japhetitische Theorie. Allgemeiner Kurs der Lehre von der Sprache. In T. Borbé (Ed.), Kritik der marxistischen Sprachtheorie N. Ja. Marr's (Skripten Linguistik und Kommunikationswissenschaft, 8) (pp. 67-262). Kronberg.

Marr, N. Ja., \& Brière, M. (1931). La langue géorgienne. Paris.

Meščaninov, I. I. (1929). Vvedenie v jafetidologiju. Leningrad.

Meščaninov, I. I. (1934). Ešče odin šag nazad. V. B. Aptekar'. Voprosy jazyka v osveščenii jafetičeskoj teorii. Izbrannye otryvki iz rabot akad. N. Ja. Marra, GAIMK, L., 1933, 560 str. Biblioteka GAIMK, No. 9, Jazyk i myšlenie, 2 (Le langage et la mentalité, 2), 131-132.

Meshchaninov, I. (1951). For a creative development of academician N. Ya. Marr's heritage. In John V. Murra, Robert M. Hankin \& Fred Hollin (Eds.), The Soviet linguistic controversy (pp. 20-28). New York.

Mixankova, V. A. (1935) 1949. Nikolaj Jakovlevič Marr. Očerki ego žizni i naučnoj dejatel'nosti. Moskva.

Murray, S. O. (1994). Theory groups and the study of language in North America. A social history (Amsterdam Studies in the Theory and History of Linguistic Sciences. Series III: Studies in the History of the Language Sciences, 69). Amsterdam. 
Nikol'skaja, T. L. (1995). Predislovie. In Ju. N. Marr, Izbrannoe. Kniga 1: proza, stixi, dramaturgija (pp. 9-12). Moskva.

Noiré, L. (1877). Der Ursprung der Sprache. Mainz.

Noiré, L. (1880). Das Werkzeug und seine Bedeutung für die Entwickelungsgeschichte der Menschheit. Mainz.

Oldenbourg, Z. (1977). Visages d'un autoportrait. Paris.

Powell, J. W. (1881). First annual report of the Bureau of Ethnology to the Secretary of the Smithsonian Institution, 1879-'80. Washington.

Sauvageot, A. (1935). Linguistique et marxisme: la théorie "japhétique" de l'académicien N. Marr. In J. Baby et al. (Eds.), A la lumière du marxisme. (Essais). Sciences physico-mathématiques - sciences naturelles - sciences humaines (pp. 160-168). Paris.

Sériot, P. (1999). Structure et totalité. Les origines intellectuelles du structuralisme en Europe centrale et orientale. Paris.

Sériot, P. (Ed.) (2005). Un paradigme perdu: la linguistique marriste (Cahiers de l'I.L.S.L, 20). Lausanne.

Šilov, L. A. (1969a). Universitet v period Velikoj oktjabr'skoj socialističeskoj revoljucii i graždanskoj vojny. In V. V. Mavrodin (Ed.), Istorija Leningradskogo universiteta: 1819-1969 (pp. 181-223). Leningrad.

Šilov, L. A. (1969b). Universitet v 1921-1927 godax. In V. V. Mavrodin (Ed.), Istorija Leningradskogo universiteta: 1819-1969 (pp. 224-328). Leningrad.

Sköld, H. (1929). Beiträge zur allgemeinen und vergleichenden Sprachwissenschaft II: Zur Verwandtschaftslehre: Die kaukasische Mode. Lund.

Slezkine, Y. (1996). N. Ia. Marr and the national origins of Soviet ethnogenetics. Slavic Review, 55(4), $826-862$.

Smuts, J. C. (1926). Holism and evolution. London.

Spencer, H. (1864) 1867. First principles. London.

Thomas, L. L. (1957). The linguistic theories of N. Ja. Marr (University of California Publications in Linguistics, 14). Berkeley, Los Angeles.

Trubetzkoy, X. (1924). N. S. Trubetzkoy's (NT) letters to R. O. Jakobson (RJ). XXII. In R. Jakobson (Ed.), N. S. Trubetzkoy's letters and notes (Janua Linguarum, Series Maior, 47) (pp. 74-75). The Hague. Paris.

Van Helden, W. A. (2008). Ekaterina Velmezova. Les lois du sens: la sémantique marriste (Slavica Helvetica, 77), Bern, etc. Peter Lang, 2007, 392 pp. The Henry Sweet Society Bulletin, 51, 61-64.

Vogt, H. (1933). N. Marr et M. Brière. La langue géorgienne. Paris, Firmin-Didot, 1931. In- $8^{\circ}$, XVI+858 pages. Journal Asiatique (fascicule annexe), 223, 142-145.

Wundt, W. (1911). Völkerpsychologie. Eine Untersuchung der Entwicklungsgesetze von Sprache, Mythus und Sitte, 1: Die Sprache. Leipzig.

Xramov, Ju. B. (2008). O zabytyx rabotax V. I. Šerclja. Acta Linguistica, 2(2), 73-78. http://open.slavica.org/ index.php/als/article/view/144/160. Accessed August 2008. 